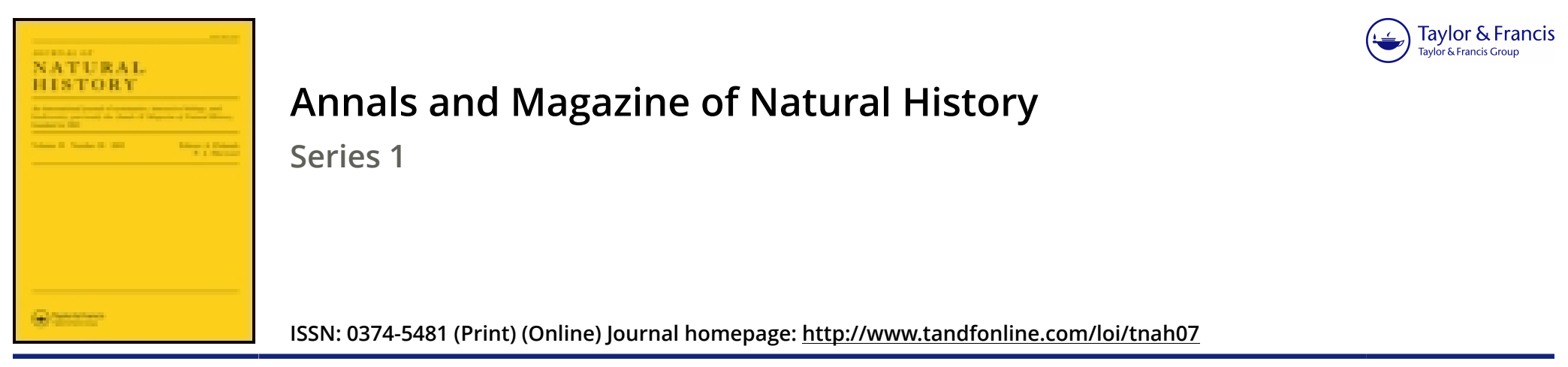

\title{
XXXIII.-Descriptions and notices of British Shells
}

\section{J. Gwyn Jeffreys F.R. L.S.}

To cite this article: J. Gwyn Jeffreys F.R. L.S. (1847) XXXIII.-Descriptions and notices of British Shells , Annals and Magazine of Natural History, 19:127, 309-314, DOI: 10.1080/037454809496475

To link to this article: http://dx.doi.org/10.1080/037454809496475

$$
\text { 曲 Published online: } 21 \text { Dec } 2009 .
$$

Submit your article to this journal $₫$

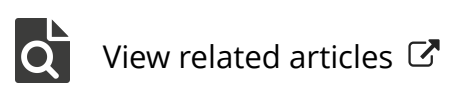

4 Citing articles: 2 View citing articles 
area just cleared of the flat table of flint. It was perfectly flat, as was the upper surface also of the flint removed. No shell of any large size was found on either surface. I observed however in several places on the upper surface lines of much the same character-though occurring for the most part only singly or fewas the lines on the specimen figure 1, and which lines I cannot. doubt owe their existence to a slight motion of the water above while the mass was in the act of solidification.

In conclusion I would remark, that, while it has been absolutely necessary for me, in order that some approach might be made to the discovery of truth on this very interesting and oftmooted question of the formation of the flints of the upper chalk, to show how much my language and views have been misrepresented, and how contrary the facts are to the representam tions, I would not for a moment be thought to imply any intentional misrepresentation in either respect on the part of $\mathrm{Mr}$. Bowerbank. It is one of the greatest evils of all "anticipation" that it tends to dim the sight and to warp the impression derived from what seems the clearest fact or statement, and that any fancied analogy (I use the word as more familiar than similitude) is seized and dwelt on to the exclusion of numberless points of dissimilitude. I trust that the observations of Mr. Bowerbank may serve to advance the discovery of truth in this matter, if they be the occasion of my rendering more clear the facts and reasons which appear to me to demonstrate the existence of numberless dissimilitudes between the facts of nature and the generalization hazarded by him, and of enabling me to render also clearer the suggestions which I have ventured to throw out, and which I would fain hope tend to elucidate in some degree the natural history of the formation of the flints of the upper chalk.

\section{XXXIII.-Descriptions and Notices of British Shells. By J. Gwyn Jefraeys, F.R. \& L.S.}

IT was my first intention to have reserved for the work on British Mollusca, in which my friend Mr. Forbes requested my assistance, the publication of any discovery on this subject which may from time to time have occurred to me ; but as in his opinion the anticipation by this mode of publication of any such discoveries would increase, instead of diminishing, the interest of the proposed work, I will give a short account of some important additions to the Catalogue of British Shells, for which I am principally indebted to my indefatigable friend and collaborateur, George Barlee, Esq., during his excursion to the western coast of Scotland last year. 


\section{Pteropoda?}

Orbis foliaceus, Philippi, vol. ii. p. 147. tab. 24. f. 26. Several specimens of this singular shell occurred to us in about fifty fathoms water off Skye. I doubt this species being the same as that of Philippi, because in perfect specimens the last whorl exceeds in size all the others so as to form an obtuse keel. One specimen is remarkable for its having two apertures occasioned by a malformation of the first, and the animal having subsequently formed another to replace it. This monstrosity is occasionally found in the shells of Gasteropods.

\section{Gasteropoda.}

Bulla pruinosa, Zool. Journ. vol. iii. p. 341. One specimen of this shell, which had not been, as far as I am aware, rediscovered by any collector since the publication of the species by Mr. Clark in 1827 as an Exmouth shell, occurred from Loch Fyne. Mr. Barlee observed a specimen in the Rev. Dr. Fleming's collection, and procured another specimen last year from Branscomb, Mr. Clark's dredger at Exmouth.

Bulla acuminata, Thil. vol. i. p. 122. t. \%. f. 18. A single specimen (although broken) from Loch Fyne. Mr. Alder informed me that he had also found one specimen on the west coast of Scotland.

Bulla truncatula, Phil. vol. i. p. 122. t.7. f. 21. Volvaria subcylindrica, Brown, p. 3. pl. 19. f. 19, 20. Several specimens of this very distinct shell occurred in from twenty to fifty fathoms from the coast of Skye.

Bulla mammillata, Phil. vol. i. p. 122. t. 7. f. 20. Skye. This species had previously been found by myself and others at Exmouth and on other parts of the south coast.

Rissoa Barleei. Shell subcylindric, smooth, solid, of a yellowish horn-colour. Volutions six, gradually increasing in size, and more or less decorticated at the top ; suture slight. Apex obtuse. Aperture oval, contracted and surrounded by a complete peristome and having the outer lip inflected towards the pillar. Umbilicus none. Length $I_{2} \frac{1}{2}$ line ; breadth $\frac{3}{4}$ of a line.

Loch Carron and Skye in twenty to fifty fathoms.

This species has very much the appearance of Rissoa (Paludina) Ulva, but differs from it in its subcylindrical form, its rather more solid texture, in not having the last volution angulated, and above all in its more contracted aperture and the peculiar inflexion of the outer lip. Its habitat is also very different. I had not an opportunity of examining the animal.

Rissoa clathrata, Phil. vol. ii. p. 223. t. 28. f. 20 ?. Cyclo. strema zetlandicum, Flem. Brit. An. p. 312.

In fifty fathoms off Skye. 
Rissoa abyssicola, Forbes. In the same locality as the last. Eulima distorta (Melania distorta, Desh.), Phil. vol. i. p. 158. t. 9. f. 10. Oban and Loch Fyne.

This species was also found many years ago by Mr. Clark at Exmouth; and several other localities in Great Britain are now known for it.

Chemnitzia rufescens, Forbes. Turritella indistincta, Flem. Brit. An. p. 304. Melania scalaris, Phil. vol. i. p. 157. t.9. f. 9 ? From the same locality as the last. I obtained it in 1843 and 1844 in various parts of the western coast of Scotland.

Eulimella (Forbes) crassula, Mal. and Conch, J. E. MacAndrei, Forbes in Ann. Nat. Hist. vol. xiv. p. 412. In many parts of the western coast of Scotland.

Eulimella gracilis. Shell elongated, of a rather thin texture, smooth, glossy, white. Volutions ten, gradually increasing in size and tapering to a point : they are rounded and well-defined by the line of separation. Aperture oval, angulated and slightly channelled at the base. Peristome not folded on the pillar. Umbilicus none. Length $\frac{4}{2}$ ths of an inch; breadth $\frac{1}{2} \frac{\text { th }}{0}$.

Several specimens of this beautiful and very distinct shell were found by Mr. Barlee at Oban, and since in Loch Fyne.

Pleurotoma variegatum, Phil. vol. i. p. 19.t. 11.f. 14. A single specimen of a shell which appears to be the above species occurred to me at Loch Carron in 1843. It differs from $\mathrm{Pl}$. purpureum in the texture of the shell being thinner, the volutions more rounded, and the longitudinal ribs more numerous.

Pleurotoma Boothii, Smith in Wern. Mem. Oban and Skye. This species is scarcely distinguishable from $\mathrm{Pl}$. lineare. I observed specimens in Mr. Metcalfe's collection of shells from Herm, one of the Channel Islands, mixed with the other species.

Pleurotoma scabrum. Shell oblong, yellowish white. Volutions six or seven, tapering and rounded, having each marked with twelve rather oblique longitudinal ribs, which are crossed by about the same number of raised transverse strix which produce tubercles at the point of junction, and are of a purplish brown colour. Suture rather deep and well-defined, showing the gradual formation and prolongation of the slit. Aperture oblong. Canal short. Umbilicus none. Length $\frac{8}{80}$ ths of an inch; breadth $\frac{3}{20}$ ths.

Two specimens of this shell were found by $\mathrm{Mr}$. Barlee at Oban.

It differs from $P l$. lineare in the volutions being more tapering, and generally in its more slender form, and in the ribs and transwerse striæ being sharper and more elevated, giving the shell a scabrous appearance.

Pleurotoma brachystomum, Phil. vol. ii. p. 169. t. 26. f. 10. Oban, Loch Carron and Skye, as well as in Bantry Bay. This 
species seems to be represented in fig. 14 of the plate to Capt. Laskey's account of North British Testacea in the Memoirs of the Wernerian Society.

Pleurotoma Ginannianum, Phil. vol. ii. p. 168. t. 26. f. 6. Ichnusa Setaba, Clark, MSS. Lerwick (1841) as well as the southern and western coasts. This species is closely allied to the last. It differs from $P l$. nebula in more abruptly tapering, having a rough aspect and the ribs being more raised and arched. The aperture is more straight and contracted. The colour is always of a uniform yellowish brown, but the $P$. nebula is yellowish white, with invariably two dark purplish bands on the last volution, one of which is continued on the upper part of each of the other volutions. This species secms also to be more common and generally distributed than the $P l$. nebula, which is a southern form.

Several of the rarer species of Pleurotoma (including Pl.teres, coarctatum, Trevelyanum, accinctum, \&c.) also occurred to us.

Buccinum Humphreysiamum, Zool. Journ. vol. i. p. $398 . \quad$ A young specimen of this shell was found by Mr. Barlee at Skye.

Emarginula crassa. Skye, Lochs Duish and Fyne.

Cemoria Noachina. Not uncommon on many parts of the western coast of Scotland.

Velutina flexilis. Skye, and by myself in 1844 at Ullapool.

Patella fulva. Not uncommon on many parts of the western coast of Scotland.

Chiton Hanleyi. Oban and Skye.

Chiton cancellatus. Ch. alveolus (Sars), Lovén, Moll. Scand. p. 27 ?

Chiton albus. On several parts of the western coast of Scotland.

One specimen of Chiton, which appears to be undescribed, was found by Mr. Barlee at Inverary; but until more specimens have been found, it is perhaps better not to assign it a distinct name at present. It resembles in form C. albus, but is more strongly beaked and the granulations are more like those in C. marginatus. The margin is intermediate between the two. Colour brownish white.

Acephata.

Terebratula seminulum, Phil. vol. i. p. 97. t. 6. f. $15 f$ ? One specimen was found by me in company with Mr. Barlee at Skye in fifty fathoms attached by its byssus.

The species is described by Philippi to be very variable in form; but I am not quite satisfied as to the identity of my shell with that species. This is half the size, of a brownish colour, and nearly smooth, whereas the T. seminulum is of a whitish colour, and thickly punctured over the surface. Further discoveries may clear up the doubt.

A depressed variety (?) of the Ostrea edulis, having the inside 
of a dark purplish colour, and nearly answering Philippi's description and figure of Ostrea depressa (vol, i. p. 89. t.6. f. 3), is occasionally found on the western coast of Scotland.

Pecten striatus, Müll. Not uncommon on many parts of the western coast of Scotland as well as of Ireland.

Pecten adspersus, Lam. Pecten danicus, Mart. and Chemn. Pecten glaber, Pennant, Br. Zool. vol. iv. p. 223 ; Mont. Supp. p. 59. t. 28. f. 6 ? Abundant in Loch Fyne, and sparingly on other parts of the western coast of Scotland. A white variety also occurs, although rarely; and another variety having strong longitudinal striæ between the ribs towards the margin.

Pecten Dumasii, Payr. p. 43. pl. 2. f. 6 and \%. Skye. I cannot agree with Philippi that this is a variety of the last. It is distinguished by being narrower, having the ribs more elevated, and close-set longitudinal prickly striæ between the ribs.

Pecten Pes-felis, Lam. Loch Long, but only single valves occurred to Mr. Barlee. land.

Pecten lavis. On many parts of the western coast of Scot-

Modiola phaseolina, Phil. vol. i. p. 51. t. 15. f. 14. On many parts of the western coast of Scotland, where it first occurred to me in 1843.

The Mod. costulata (Risso), Phil. vol. i. p. 50. t. 15. f. 10, has occurred to me on the southern and western coasts of England.

Nucula Polii, Phil. vol. i. p. 63. t. 5. f. 10. Oban. This species has also been found in Dublin Bay, and I believe in other parts of Scotland and Ireland.

Leda (Sćhumacher) tenuis. Nucula tenuis, Phil. vol. i. p. 65. t. 5. f. 9. Leda pygmaa, Forbes in Mem. of Geol. Surv. p. 419. Not uncommon on the coast of Skye.

Arca pectunculoides (Scacchi), Phil. vol. ii. p. 44. t. 15. f. 8. With the last.

Cardium suecicum (Loveni al.). Oban, and on many other parts of the western coast of Scotland.

Cardium nodosum. Lerwick in 1841, and with the last.

Tellina balaustina, Poli. Skye. This is the second occurrence of this beautiful species in this country.

Lucina spinifera. On many parts of the western coast of Scotland.

Poronia (?) ferruginosa.

Artemis (?) ferruginosa, Forbes. In 50 to 100 fathoms, Skye and Loch Fyne: some specimens from the latter place are double the usual size.

Venus Plagia. Shell oblong, compressed, brownish white, glossy, marked transversely with antiquated ridges, which are stronger towards the margin and anterior extremity, and crossed 
longitudinally by oblique stria which diverge from the hinge to the margin. There is a strongly developed flexuosity at the an. terior extremity which terminates in rather an acute edge. Hinge as in $V$. Pullastra. Breadth $1 \frac{5}{8}$ inch ; length 1 inch.

A single valve of this size occurred to me at Lerwick; a small live specimen at Deal Voe in the Shetlands; and a still smaller specimen was found by Mr. Barlee in Loch Fyne.

It has a considerable resemblance to $V$. Pullastra, but it differs in the peculiar obliquity of its form as well as its greater breadth and other particulars.

Astarte crebricostata, Forbes in Ann. Nat. Hist. vol. xix. p. 98. Skye, but only single valves were found.

Many specimens of Astarte were extremely difficult, if possible, to be distinguished specifically, and the variety of form in this genus is very puzzling. I am quite satisfied that the crenulation of the margin is not a specifically distinctive character; nor the number of ribs, nor the form, much less the size or colour. With respect to size, I may observe that specimens of $A$. compressa measured more than three-quarters of an inch in diameter.

Psammobia (?) plicata. Mytilus plicatus, Mont. Suppl. p. 70; Laskey in Wern. Mem. pl. 8. f. 2. Two single valves of this curious shell were found by us in fifty fathoms off Skye. Mr. Hanley had previously taken it at Ryde.

It has much the aspect of a Panopar.

Psammobia costulata.

Psammobia strigillata. Skye.

Corbula (?) granulata, Nyst, Belg. Foss. p. 71. pl.2. f. 6. Tellina polygona, Mont.? I dredged one (live) specimen of this curious shell in fifty fathoms off Skye.

Neara abbreviata, Forbes. Between seventy and eighty specimens of this shell were procured by Mr. Barlee in Loch Fyne.

Many other extremely rare and interesting shells occurred, but I have already I fear trespassed too long on the columns of this month's 'Annals.'

XXXIV.-Notes on the genus of Insects Omias, with descriptions of new species. By John W Alton, F.L.S.

Fam. CURCULIONID 皮.

Genus Omias, Germ. olim, Schönh., Latr., Dej., Sturm. Thylacites (Brachysomus), Schönh. olim.

Otiorhynchus, Brachysomus, Steph.

Char. Gen. "Antennæ moderate, either slight or rather stout; scape generally longer than the head, more or less curved, towards the apex incrassated; first and second joints of the funi- 